\title{
Yellow fever and Hajj: with all eyes on Zika, a familiar flavivirus remains a threat
}

\author{
Qanta A. Ahmed ${ }^{1}$, Ziad A. Memish $(\bowtie)^{2,3}$ \\ ${ }^{I}$ Division of Pulmonary Disease and Critical Care Medicine, Department of Medicine, Winthrop University Hospital; State University of New \\ York (SUNY) at Stony Brook, NY 11790, USA; ${ }^{2}$ Ministry of Health, Riyadh 11514, Kingdom of Saudi Arabia; ${ }^{3}$ College of Medicine, Alfaisal \\ University, Riyadh 11533, Kingdom of Saudi Arabia
}

(C) Higher Education Press and Springer-Verlag Berlin Heidelberg 2016

\begin{abstract}
Hajj is among the world's largest mass gatherings, drawing between 2 and 3.5 million Muslims from 183 nations annually to perform pilgrimage in Mecca, Saudi Arabia. Infectious disease outbreaks can be imported both into the Hajj population and exported internationally by returning pilgrims. The domestic Saudi population can also be at risk of outbreaks traveling amid this mass migration. With yellow fever reported for the first time in China following the infection of expatriate Chinese workers in Angola and a full blown outbreak underway in wider West Africa, the prospect of yellow fever outbreaks in Asia threatens to impact Saudi Arabia, both during and beyond the Hajj season. With global focus trained on Zika, the rising threat of yellow fever cannot be overlooked. Strategies to mitigate risk to Saudi Arabia and the global population are thereby suggested.
\end{abstract}

Keywords yellow fever; mass gathering; Saudi Arabia; Hajj; Zika virus

While global attention has been rightly focused on Zika virus, the first infectious disease to result in congenital birth defects in over half a century, it is important not to lose sight of other flavivirus pathogen threats impacting Asia at this time [1,2]. This week one of the largest mass gatherings in the world takes place in confined geographic locations when close to 2 million Muslims assemble to perform Hajj in and around Mecca. The Hajj draws Muslims from over 183 countries each year, including by 2013 data, $14 \%$ of pilgrims from 46 different yellow fever endemic countries [2]. China's identification of 13 nonvaccinated travelers originating from West Africa with yellow fever earlier this month is thought to place around one billion people at risk [3]. With the "global hub" impact of Hajj, serious outbreaks and even epidemics of yellow fever become a risk in the countries of origin of returning pilgrims [4].

Unlike Zika virus, which frequently produces minor symptoms easily missed by infected individuals up to $80 \%$ of the time, yellow fever is a hemorrhagic disease with high mortality rates of $15 \%$ to $50 \%$ and no possible cure $[5,6]$. Unlike Zika, yellow fever is vaccine preventable

Received September 14, 2016; accepted September 14, 2016

Correspondence: Zmemish@yahoo.com (even as hopes to develop a Zika virus remain high at the time of writing). Both Zika virus and yellow fever virus share the same mosquito vector-Aedes aegyptii, known to be present in Jeddah (Table 1). While a total number of 16 sites of entry can be used, whether by air or land or sea, Jeddah is the point of ingress for the vast majority of Muslim pilgrims whether arriving for Hajj or Umrah in the three months preceding Hajj known as Hajj season (Fig. 1).

Up to ten million Muslims travel through Jeddah to complete these rituals, exposing huge numbers to active flavivirus. Matters are complicated by co-circulation and co-infection of Aedes aegyptii, which can carry either Zika virus or yellow fever virus or even Chikungunya virus - a third form of flavivirus. Co-circulation and co-infection with multiple flaviviruses delay diagnosis. Rapid travel through both mass gathering and internationally mobile populations as Hajj season involves further complicates these difficult diagnoses. Together all these factors escalate the likelihood of yellow fever outbreak at Hajj and subsequent dissemination of yellow fever in ever wider regions.

Concerning yellow fever, patterns of epidemiology are changing: the yellow fever virus's life cycle is moving from a jungle-based to urban-based. During the jungle cycle, humans are mere incidental hosts, but in the densely populated urban environment sustained transmission of the 


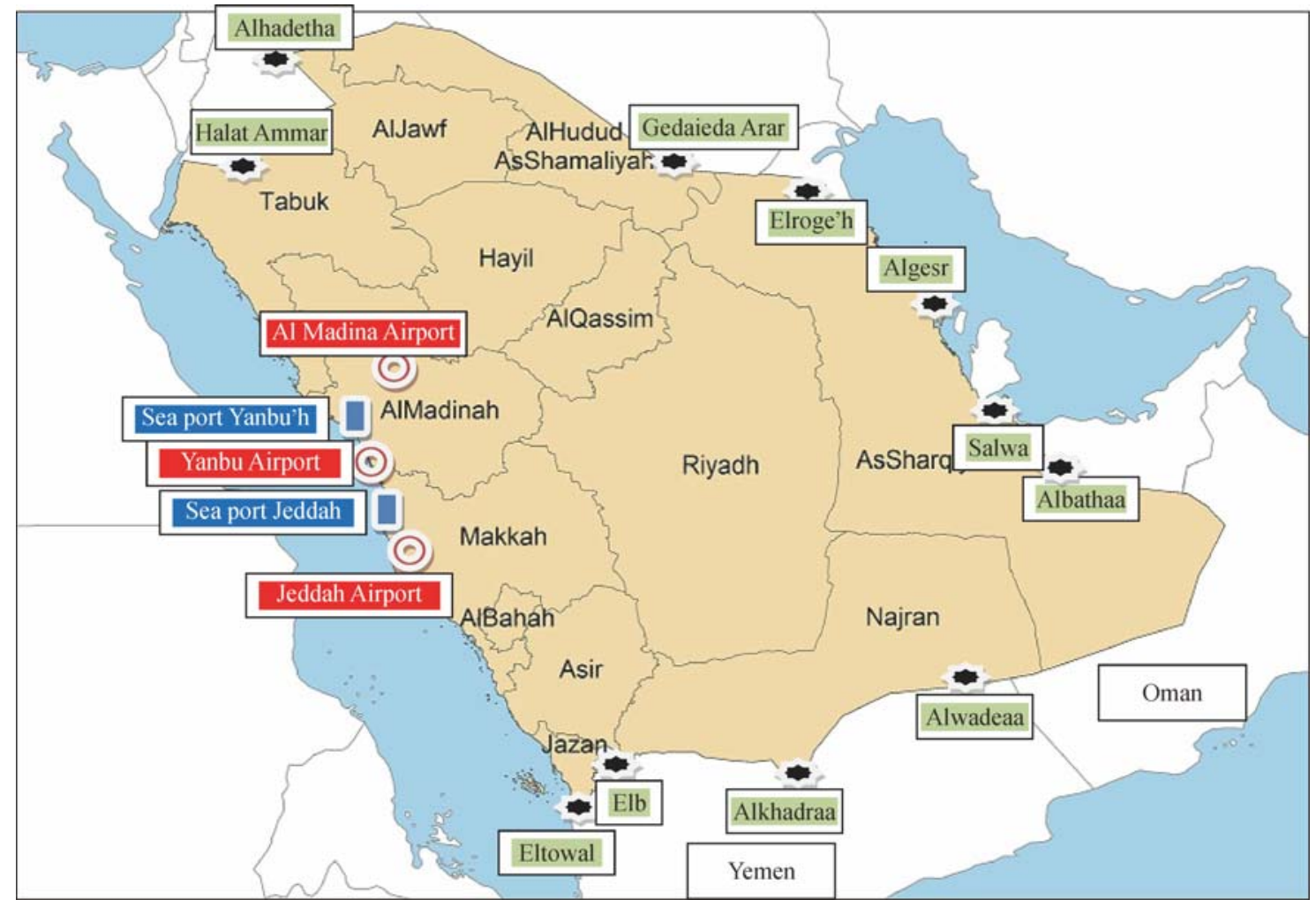

Fig. 1 Map of Saudi Arabia indicating all (sea, air, and land) ports of entry for Hajj.

virus propagates amid humans. Human travel, particularly global jet travel (as well as the high population density of most urban environments) intensifies yellow fever infection risk.

By mid July 2016, in West Africa alone, 6000 cases of yellow fever resulted in 446 deaths [7,8]. Recognition that yellow fever virus is traveling rapidly has resulted in a depletion of national stocks of the yellow fever vaccine twice over - stockpiles of 6 million units of vaccine have been depleted twice over $[9,10]$. Reflecting a tremendous strain on limited resources, the WHO has announced the use of one-fifth strength of the usual vaccine dose as a vaccine campaign in a desperate effort of containment. Whether this results in arresting the spread of yellow fever is yet to be seen.

Matters are worsened given the difficult and lengthy development of yellow fever vaccine which takes at least 12 months to produce. Each year, predictions of the demand for yellow fever vaccine supply vary and in 2016, even before the global threat of Zika virus had become apparent, demand for yellow fever vaccine supply had already become unusually high, because of the yellow fever outbreak first in Angola and then in the Democratic Republic of Congo. No prior year has ever required more than 4 million units of yellow fever vaccine previously, a startling contrast to this year's demands on vaccine supply leading the WHO to make unprecedented recommenda- tions to utilize the vaccine at one-fifth of its customary dose - a sign of desperate improvisation. Including Uganda - where outbreaks had been recorded cumulatively these three nations consumed more than 18 million doses of yellow fever vaccine. Vaccine supply of yellow fever is now globally depleted. While we understand the need for reducing the dose in theory to prevent continued transmission, inoculating each patient with less than a full yellow fever vaccine dose is in contradiction to the WHO's own criteria for certified immunization. Further, reaching the massive populations of the potentially afflicted requires adequate syringe supply and adequately trained manpower. Despite awareness of yellow fever morbidity and even lethality, affected areas have poor uptake of vaccination in the past and only $12 \%$ of impacted nations have a greater than $80 \%$ vaccination rate ensuring that transmission of yellow fever continues in these endemic areas which then seed ongoing outbreaks both domestically and internationally $[11,12]$.

Shortfalls in both vector transmissions in air travel and adequate vaccination ensure that for now we can expect to see more yellow fever outbreaks and perhaps a spike in the weeks after Hajj when millions of pilgrims from flavivirus affected areas return home possibly viremic or transporting the infected virus in the vector itself [13]. For now, standard anti mosquito protocols should be followed in all endemic areas in Saudi Arabia but especially in Jeddah. At 
Table 1 Comparison between yellow fever and Zika virus

\begin{tabular}{|c|c|c|}
\hline & Yellow fever virus & Zika virus \\
\hline \multirow[t]{2}{*}{ Causative virus } & $\begin{array}{l}\text { YF virus } \\
\text { (Flavivirus) }\end{array}$ & $\begin{array}{l}\text { Zika virus } \\
\text { (Flavivirus) }\end{array}$ \\
\hline & Single stranded RNA & Single stranded RNA \\
\hline Non-human host & Forest-dwelling non-human primate & Non-human primate (Rhesus monkey) \\
\hline Vector & Aedes mosquitos & Aedes mosquitos \\
\hline Incubation period & $3-6$ days & 3-12 days \\
\hline Geographic distribution & Tropical rain forests of Africa and South America & $\begin{array}{l}\text { Africa, the Pacific Islands, South-east Asia, large part } \\
\text { of South/Central America, a number of islands in the } \\
\text { Caribbean, including Puerto Rico, the Virgin Islands, } \\
\text { and Mexico }\end{array}$ \\
\hline Human-to-human transmission & $\begin{array}{l}\text { Breast feeding } \\
\text { Exposure to infected blood/organs }\end{array}$ & $\begin{array}{l}\text { Mosquito bites } \\
\text { From a pregnant woman to her fetus } \\
\text { Sexual contact } \\
\text { Blood transfusion } \\
\text { Contact with tears }\end{array}$ \\
\hline Clinical features & $\begin{array}{l}\text { Asymptomatic } \\
\text { Mild febrile illness } \\
\text { Severe disease with jaundice } \\
\quad \text { and hemorrhage }\end{array}$ & $\begin{array}{l}\text { Asymptomatic }(80 \%) \\
\text { Mild febrile illness: headache; arthralgia; myalgia; } \\
\text { conjunctivitis; fever; vomiting; maculopapular rash; } \\
\text { prostration; edema of extremities }\end{array}$ \\
\hline Complications & Liver failure, renal failure, DIC & $\begin{array}{l}\text { Congenital microcephaly, Guillain Barrie syndrome, } \\
\text { meningoencephalitis, acute myelitis }\end{array}$ \\
\hline Mortality (\%) & $20-50$ & 0 \\
\hline Diagnostic test & $\begin{array}{l}\text { Virus isolation, viral antigen in tissue, viral } \\
\text { RNA in blood and tissue (RT-PCR), serology }\end{array}$ & Viral RNA in blood (RT-PCR), serology \\
\hline Prevention & $\begin{array}{l}\text { Vaccine } \\
\text { Mosquito prevention measure }\end{array}$ & $\begin{array}{l}\text { No vaccine } \\
\text { Mosquito prevention measure }\end{array}$ \\
\hline
\end{tabular}

risk zones must be targeted by looking at past dengueimpacted areas where Aedes aegypti has been incriminated as the vector. Physicians and public health planners must maintain acute vigilance for Zika virus and hemorrhagic fever surveillance with robust epidemiology and laboratory surveillance [14]. Data must be immediately disseminated. While we hope for a peaceful and successful Hajj, we are expecting a rise in reported instances of yellow fever. Post Hajj, authorities will have to search intensely and aggressively for yellow fever endemicity and infection. Vaccine stockpiles should be stored as a matter of urgency, and if yellow fever outbreaks are documented, evidence of yellow fever vaccination for all religious tourists to Saudi Arabia from the 46 endemic nations should be enforced until better containment of yellow fever is achieved. In addition, effective vector control measures in areas infested with Aedes aegypti must be strengthened while pilgrims must be educated on preventive measure. Vector control agents must be made available to all pilgrims traveling to Saudi Arabia [2].

\section{Compliance with ethics guidelines}

Qanta A. Ahmed and Ziad A. Memish declare that they have no conflict of interest. This manuscript is a commentary and does not involve a research protocol requiring approval by the relevant institutional review board or ethics committee.

\section{References}

1. Wasserman S, Tambyah PA, Lim PL. Yellow fever cases in Asia: primed for an epidemic. Int J Infect Dis 2016; 48: 98-103

2. Elachola H, Ditekemena J, Zhuo J, Gozzer E, Marchesini P, Rahman M, Sow S, Kattan RF, Memish ZA. Yellow fever outbreaks, vaccine shortages and the Hajj and Olympics: call for global vigilance. Lancet 2016 Sep 5. [Epub ahead of print] doi: 10.1016/S0140-6736 (16)31546-X

3. Wang L, Zhou P, Fu X, Zheng Y, Huang S, Fang B, Zhang G, Jia K, Li S. Yellow fever virus: increasing imported cases in China. J Infect 2016; 73(4):377-380

4. Gulland A. Vigilance still needed to contain Africa's yellow fever outbreak, says WHO. BMJ 2016; 354:i4756

5. Beasley DW, McAuley AJ, Bente DA. Yellow fever virus: genetic and phenotypic diversity and implications for detection, prevention and therapy. Antiviral Res 2015; 115: 48-70

6. Monath TP, Vasconcelos PF. Yellow fever. J Clin Virol 2015; 64: $160-173$

7. Burki T. Yellow fever in Africa: a disaster waiting to happen. Lancet Infect Dis 2016; 16(8): 896-897

8. Maguire HC, Heymann DL. Yellow fever in Africa. BMJ 2016; 354 : i3764

9. WHO. Yellow fever global vaccine stockpile in emergencies. http:// 
www.who.int/features/2016/yellow-fever-vaccine-stockpile/en (Accessed September 10, 2016)

10. Jamie A. Yellow fever spreads rapidly in Africa, vaccine supply running low. http://www.natureworldnews.com/articles/23986/ 20160621/yellow-fever-spreads-rapidly-africa-vaccine-supply-running-low.htm (Accessed September 10, 2016)

11. Barrett AD. Yellow fever in Angola and beyond - the problem of vaccine supply and demand. N Engl J Med 2016; 375(4): 301-
303

12. Kupferschmidt K. Yellow fever outbreak triggers vaccine alarm. Science 2016; 352(6282): 128-129

13. No authors listed. Health conditions for travellers to Saudi Arabia for the pilgrimage to Mecca (Hajj), 2016. Wkly Epidemiol Rec 2016; 91(26-27): 331-335

14. Mo Y, Alferez Salada BM, Tambyah PA. Zika virus - a review for clinicians. Br Med Bull 2016; 119(1): 25-36 